\title{
Culinary Industry Health Product in Surakarta, Indonesia: Health Policy Guaranteeing Halal and Healthy Products
}

\author{
Nunik Nurhayati*(D), Khudzaifah Dimyati(D, Absori AbsoriD, Kelik Wardiono (D), Muchamad Iksan, Rizka Rizka(D), Harun Harun (iD \\ Department of Law, Faculty of Law, Universitas Muhammadiyah Surakarta, Surakarta, Indonesia
}

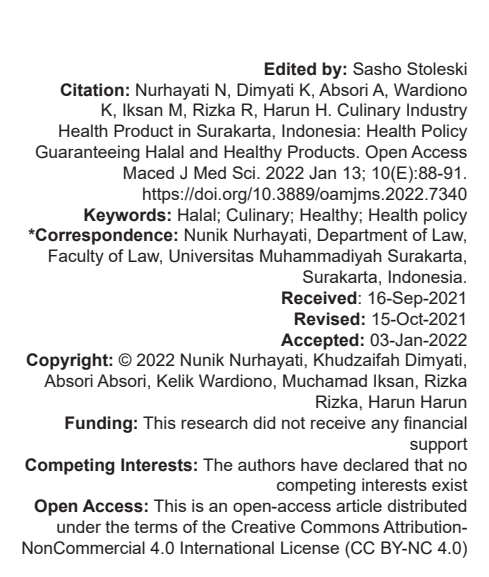

\section{Introduction}

Economically, Indonesia is an industrial country, as industries contribute more than $20 \%$ of the national economy [1]. The culinary industry is one of the 16 subsectors of the creative industry in Indonesia. In 2016, the culinary industry contributed $41.4 \%$ to Indonesia's gross domestic product or Rp 922 trillion [2]. The growth of the food and beverage industry in 2017 reached $9.23 \%$, an increase compared to 2016 of $8.46 \%$ [3]. Product quality, health, and sanitation issues are major concerns in the food industry [4].

Al-Asy'ats, a Muslim scientist at the end of the $4^{\text {th }}$ century, researched halal and health food. He stated that some foods may develop growing intelligence [5]. Then, Shaykh Taqi Falsafi corroborates his opinion by citing Alexis Carrel, winner of the Nobel Prize in Medicine, "But there is no doubt that human feelings are influenced by the quality and quantity of food" [6].

Halal and health food guarantees are required in developing Indonesia's culinary. However, food poisoning or unhealthy food may cause illnesses or even death [7]. There are about 200 more diseases that can arise due to unhealthy food [8]. Human bodies are closely related to food hygiene. The Indonesian government shows its commitment by ratifying Law Number 33 of 2014 concerning Halal Product Guarantee. It guarantees the legal certainty of a product's halal and health status in terms of manufacturing materials and manufacturing processes to the packaging stage [9]. All of this policy is for the publics especially Muslims majority's health and hygiene food. Halal assurance of a product not only guarantees the halalness of a product but also the goodness and hygiene of the product. In his book, Ma'ruf Amin [10] writes that halal-certified products are not only in demand by Muslims but also non-Muslim communities, because non-Muslims think that halal products are proven to be of high quality and very good for the health of the human body.

In 2017, Indonesia's population reached 261.9 million [11]. This number increased in 2019 reaching 269.6 million people [12]. With most of its population consisting of Muslims, it is no wonder that Indonesia is globally at the first rank of the highest Halal and Food consumer [13] with total spending of USD 170 billion (Figure 1) [14].

This is a huge potential for the food product industry. Halal is a universal concept, covering all aspects of quality, hygiene, health, and other services. Halal 


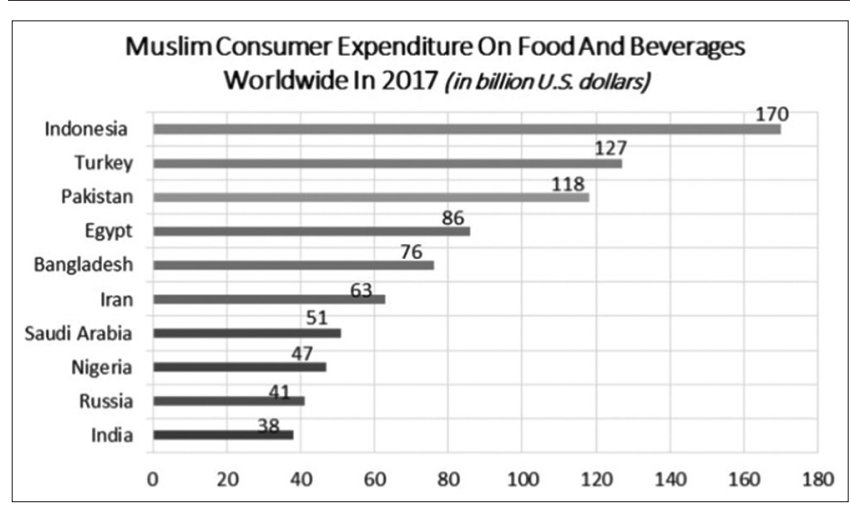

Figure 1: Muslim consumer expenditure 2017

certificates provide added value to the food products, to increase their marketability [15]. Most foods made in large industrial scales have obtained the halal certificate. However, $50 \%$ of food producers in the small and medium industry sector did not understand halal certification [16].

Every legal system consists of three subsystems, namely, legal substance (legal material), legal structure, (law enforcing institutions), and legal policy [17]. In this case, the legal substance is Law Number 33-year 2014 concerning Halal Product Guarantee. The legal structure is the Halal Product Guarantee Agency which functions to guarantee the halal status of products in Indonesia. Legal policy is in the government policy to enact a policy to form of small-scale food producers' in guaranteeing halal and health products. This paper is the result of research on small and medium industrial food producers in ensuring the halal status of products in Surakarta City.

The requirements for the law to be effective are the existence of laws that apply in the community, the implementation of the law, and the socio-economic conditions of the community. The contents of the laws made must regulate, prohibit, and contain morality. Law 33 of 2014 as a breakthrough in guaranteeing halal products for the community is more about the formation of a special institution, namely, the Halal Product Guarantee Agency. Regarding sanctions, in articles 56 and 57 , criminal provisions are given to industrial actors who falsify halal certificates and everyone involved in the implementation of the halal assurance process who leaks secrets/formulas of business actors in the process. The absence of sanctions rules if industry players do not take care of halal certificates makes the implementation of policies counterproductive.

\section{Methods}

This is empirical juridical research, a type of sociological legal research (field research). It uses a combination of qualitative and quantitative approaches.
The former is used to obtain data on ethical concepts and legal awareness in obeying statutory regulations. Then, the latter is carried out by taking samples using systematic random sampling to obtain respondents, namely, small and medium business entrepreneurs in the culinary field at five different sub-districts in the Surakarta City area. Respondents amounted to 70 people who were selected by region. The selection of respondents was carried out randomly according to the subjectivity of the researcher where according to the researcher they were the appropriate respondents. The selection of respondents was not based on religion. However, the researcher in the interview instrument included religion considering that halal products are Islamic teachings and found that $81 \%$ of the respondents were Muslim. Respondents are decision makers in their business where respondents are $71 \%$ owners and $23 \%$ employees. The data are obtained through surveys on the respondents using research questionnaires.

\section{Results}

\section{The government policy and behavior of food producers in Surakarta}

The behavior of small and medium industries was surveyed to 131 respondents, namely, food producers in Surakarta City (Table 1).

Table 1: The importance of halal food

\begin{tabular}{lll}
\hline No. & Importance & Percentage \\
\hline 1 & Very Important & 29.77 \\
2 & Important & 58.02 \\
3 & Not Important & 12.21 \\
\hline
\end{tabular}

Although many think that halal certification is important, not many small and medium industry actors have obtained halal certificates $-83.97 \%$ of respondents never obtained halal certification. This means that only $16.03 \%$ of small and medium industry actors have had their products certified.

Based on Law 33 of 2014, the government reaction as still many not obtained halal certificate just only gives repressive authority to the government in terms of counterfeiting halal certificates. In terms of ownership of a halal certificate, it is not mandatory so that there are no sanctions if the food industry actor does not have a halal certificate. Hence, preventive measures that can be taken by the government are optimizing several related institutions such as the Halal Product Guarantee Agency and the Ministry of Industry's Center for Halal Industry Empowerment to create programs that make it easier for food industry players to have halal certificates. Local governments can also make policies such as socialization, facilitation, and providing subsidies to small and medium-sized industry players to have halal certificates for their food products. 
In the Government, enaction of halal and health foods is sources to create a health policy to ensure the food producers obedience to fulfill their obligation [18]. The awareness of the halal certification does not directly encourage culinary small-medium enterprises (SMEs) to obtain a halal certificate, but the government could it makes them pay attention to the food-making process so that products remain halal and healthy (Table 2).

Table 2: Factors that discourage culinary SMEs from obtaining halal certification

\begin{tabular}{lll}
\hline No. & Factor & Percentage \\
\hline 1 & Business will run without certification & 54.83 \\
2 & No relationship between certification and consumer trust & 22.58 \\
3 & Halal certification is not according to beliefs & 19.35 \\
4 & Lack of funds to obtain certification & 3.23 \\
\hline SMEs: Small-medium enterprises.
\end{tabular}

Several factors discourage culinary SME actors in Surakarta from obtaining halal certification. The survey shows that $54.83 \%$ of respondents believe that their businesses will run even without certification. They believe that the most important thing is to maintain the halal status of the food even without certification. This is also due to the lack of law enforcement or government policy to enforce them.

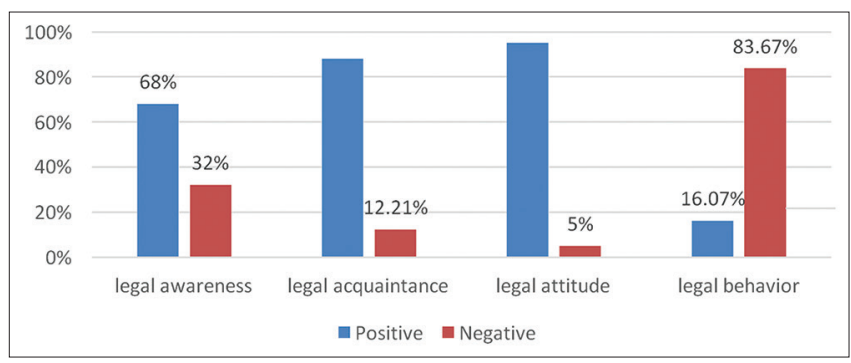

Figure 2: Indicators of legal awareness of small entrepreneurs in the culinary sector in Surakarta

Then, $22.58 \%$ of respondents believe that there is no relationship between halal certificates and customer trust. There is an attitude of mutual trust between sellers and consumers even without certificates. Next, $19.35 \%$ state that halal certification is not according to their beliefs. Then, $3.23 \%$ of respondents state that their income is not enough to pay for halal certificate registration.

\section{Ethical concepts of halal and health food product}

Law number 33 of 2014 on Halal Product Guarantee has not become the main guarantor in providing halal and health food product assurance to the public. The existence of a regulation is not necessarily followed by people's compliance, but it is obtained through the social and policy mechanism and the regulation of halal and health labeling. Even though the regulations on halal certification have been in effect for a long time, culinary micro and small enterprises (MSE) seldom applies it microscale food entrepreneurs (small entrepreneurs). According to the observations made by researchers on packaged food circulating in Surakarta City, there are still many foods that are packaged with halal labels but are not accompanied by registration codes from the Indonesian Islamic Scholar Assembly (MUI/Majelis Ulama Indonesia) nor the Indonesian Food and Drug Association.

Indicators of culinary MSE's behavior of the halal food certification are shown in Table 3 and Figure 2.

Table 3: Legal awareness indicators of culinary MSEs in Surakarta City

\begin{tabular}{lllll}
\hline No. & Indicator & Description & Positive & Negative \\
\hline 1 & Legal awareness & $\begin{array}{l}\text { Respondents' positive } \\
\text { knowledge on halal certification }\end{array}$ & $68 \%$ & $32 \%$ \\
2 & Legal acquaintance & $\begin{array}{l}\text { Respondents' belief on the } \\
\text { importance of halal certification }\end{array}$ & $87,79 \%$ & $12,21 \%$ \\
3 & Legal attitude & $\begin{array}{l}\text { Respondents' support for the } \\
\text { implementation of regional } \\
\text { regulations on halal assurance }\end{array}$ & $95 \%$ & $5 \%$ \\
4 & Legal behavior & $\begin{array}{l}\text { Respondents' compliance by } \\
\text { owning halal certificate for their } \\
\text { products }\end{array}$ & $16.33 \%$ & $83,67 \%$ \\
\hline MSE: Micro and small enterprises. & & & \\
\hline
\end{tabular}

\section{Discussion}

Legal compliance cannot be separated from a public policy and legal awareness. A person will easily appear to comply with the law if he realizes its importance. It is impossible for a person to obey the law if he does not understand the law. The ability to understand the law will be followed by the ability to judge it, whether the law is fair or not [19]. Legal compliance is another element of a broader problem, namely, legal awareness. Legal awareness is also related to the issue of knowledge, recognition, and respect for the law [20].

Philosophically, the term "ethics" is a scientific theory that discusses what is health and what is bad concerning human behavior. Ethics is an effort to formulate a theory on the administration of a health life. Ethical problems arise when the morality of a person or a society begins to be reviewed critically [21].

Ethics is also needed in business especially in food and culinary production activities as it does not only aim for profit, but it must consider human and health values. Business is carried out between humans with one another, so it requires ethics as a guide in decision-making and human behavior in dealing with one another. There is currently tight competition in businesses, thus people who pay attention to ethical norms in an increasingly professional climate will win.

There are three basic principles of ethical behavior, namely:

1. Avoid seemingly trivial ethical violations, as consumer trust depends on the food producers track record 
2. Focus on long-term reputation. The commitment of food producers to use halal raw materials can result in a producers of halal and health in longterm reputation

3. Be prepared to face unfavorable consequences when adhering to ethical behavior [22].

Islamic guidelines on ethics as a basis for growing public awareness can be one of the elements of law enforcement of Law number 33 of 2014 concerning Halal Product Guarantee. This can be a driving force for legal culture regarding the behavior of food producers in guaranteeing halal products. There is a close relationship between health and policy because the fields of discussion both revolve around the problem of human actions [23].

Law and policy for health and halal can be able building attitudes and changing the mentality of the nation, which has been burdened with negative stigmas as a nation that tends to be tolerant of law violations. This is important considering that law enforcement, especially product halal and assurance to the public, is very dependent on how strong the ethics, integrity, and commitment of government and food business actors are.

If there are any falsification or others, the legal impact or sanctions in Law number 33 of 2014 are if there is evidence that there is non-halal content in products that have been certified halal. The business actor concerned can be sentenced to a maximum imprisonment of 5 years or a maximum fine of IDR 2 billion. For the case to be processed according to the criminal law, the consumer or the public must report the allegation to the police.

\section{Conclusion}

Results show that $87.79 \%$ of respondents are aware of the halal certification's importance, but only $16.07 \%$ had the halal certification. This shows that the level of compliance is still low. Islamic guidelines on ethics can be one of the elements in enforcing Law number 33 of 2014 concerning Halal Product Guarantee. However, non-compliance does not only come from a lack of ethics. Respondents stated that they pay attention to the process in food production so that they are guaranteed halal and healthy food, but due to technical constraints and costs in obtaining halal certification, not many people register for halal certification. Health policy, ethics, legal awareness, authorized institutions, and regulations must complement each other to guarantee halal and health foods for the community.

\section{References}

1. Indonesia's Ministry of Industry. Indonesia is an Industrial State, Kemenperin; 2017. Available from: https://www.kemenperin. go.id/artikel/18473/indonesia-masuk-kategori-negara-industri [Last accessed on 2021 Jun 01].

2. Agmasari S. Culinary Industry, Strongest Supporter of Indonesia's Creative Economy, Kompas; 2018. Available from: https://www.travel.kompas.com/read/2018/02/06/185000027/ industri-kulinerpenopang-tertinggi-perekonomian-kreatif-diindonesia [Last accessed on 2019 Sep 24].

3. Yasmin PA. Ministry of Industry: The FNB Industry Grows 9 , 23\%, Detik; 2018. Available from: https://www.finance.detik.com/ industri/d3985814/menperin-industri-makanan-danminumantumbuh-923 [Last accessed on $2021 \mathrm{Jul}$ 15].

4. Sadiku M, Musa S, Ashaolu TJ. Food industry: An introduction. Int J Trend Sci Res Dev 2019;3:128-30.

5. Waharjani E. Halal and health food and the implications to one's piety. J Komunikasi Pendidikan Islam. 2015;4(2).

6. Shihab MQ. Grounding the Koran. Bandung: Mizan; 2008.

7. Andriyani A. Literature review on feed in the perspectives of Islam and health. J Kedokteran Kesehatan. 2019;15(2):2163942. Available from: https://www.jurnal.umj.ac.id/index.php/jkk [Last accessed on $2021 \mathrm{Jul} 15]$.

8. World Health Organization. Who Estimates of the Global Burden of Foodborne Diseases. Geneva: WHO; 2015.

9. Warto $S$. Halal certification and its implications to halal product businesses in Indonesia. Al Maal. 2020;2(1):2580-3816. Available from: http://www.jurnal.umt.ac.id/index.php/jieb

10. Ma'ruf A. Fatwa Produk Halal Melindungi dan Menentramkan. Jakarta: Pustaka Jurnal Halal; 2010.

11. Indonesia Statistics. 2010 Population Census Based on Area and Religion, BPS; 2010. Available from: https://www.sp2010.bps. go.id/index.php/site/tabel?tid=321 [Last accessed on 2021 Apr 21].

12. Faqiatul MW, Anissa HP. Development model of halal food industry in Indonesia. Muqtasid. 2018;9(1):1-13.

13. Reuters T. State of the Global Islamic Economy Report 2017/2018. Dubai the Capital of Islamic Economy; 2018

14. Shahbandeh M. Top Five Global Muslim consumer Food Expenditure 2017 by Country, Statista; 2019. Available from: https://www.statista.com/statistics/737162/global-muslim-foodand-beverage-market Last accessed on [2021 Feb 11].

15. Jabbar AA. Halal Certification is a Standard in the Food Industry; 2019. Available from: https://www.madaninews.id/8054/ sertifikasi-halal-telah-menjadi-standar-dalam-industri-pangan. html [Last accessed on 2021 Jun 11].

16. Huda N. Food producers' understanding on halal certification: Case study in Surakarta. Ishraqi. 2012;10(1):193-204.

17. Friedman LM. American Law an Introduction. Jakarta: Tatanusa; 2001.

18. Hastjarjo D. Introduction to consciousness. Bul Psikol. 2005;13(2):854-7108.

19. Soemitro RH. Legal Studies and the Society. Bandung: Alumni; 1985.

20. Soekanto S. Legal Awareness and Legal Compliance. Jakarta: CV Radjawali; 1982.

21. Hidayat K. Ethics in the Holy Books and the Relevance in Modern Life: Case Study in Turkey, Yayasan Paramadina. Available from: http://www.media.isnet.org/kmi/islam/paramadina/ konteks/etika2.html [Last accessed on 2021 Jul 11].

22. Arifin J. Dialectics of Islamic and Western Ethics in Business. J. Millah. 2008; (8)1; pp 145-168.

23. Laoly YH. Legal Awareness and the Achievement of Justice for All Indonesians. Probolinggo: Universitas Nurul Jadid; 2019. 